\title{
Evaluation of In-vitro Anticoagulation Activity of 35 Different Seaweed Extracts
}

\author{
Seon-Mi Ahn, Yong-Ki Hong', Gi-Seok Kwon ${ }^{2}$ and Ho-Yong Sohn* \\ Department of Food and Nutrition, Andong National University, Andong 760-749, Korea \\ ${ }^{1}$ Department of Biotechnology, Pukyong National University, Busan 608-737, Korea \\ ${ }^{2}$ The School of Bioresource Science, Andong National University, Andong 760-749, Korea
}

Received August 11, 2010 /Accepted October 1, 2010

\begin{abstract}
Seaweeds have been recognized as a health food, having anti-obesity, anti-constipation and anticoagulation activities, and the use of seaweeds in the food, medicine, and cosmetic industries have recently significantly increased. In this study, methanol extracts were prepared from 35 different seaweeds (17 phaeophyta, 11 rhodophyta and 7 chlorophyta), and thrombin time (TT), prothrombin time (PT) and activated partial thromboplastin time (aPTT) were determined in order to develop safe and novel anticoagulation agents from natural products. In TT experiments, Ecklonia cava, Ecklonia stolonifera, Eisenia bicyclis (Kjellman) Setchell, Ishige foliacea, I. okamurai, Sargassum confusum and S. yamade showed strong thrombin inhibition activity among the 35 different seaweeds. In PT experiments, the inhibitions of prothrombin were identified in the selected seaweeds from TT experiment, with the exception of $S$. yamade In aPTT experiments, the seaweeds with blood coagulation inhibition factors were E. cava, E. stolonifera, E. bicyclis (Kjellman) Setchell, I. foliacea, I. okamurai, S. confusum and Hixikia fusiforme Okamura. Further anticoagulation assay with the selected 8 seaweeds suggested that $S$. confusum is most effective in antithrombosis, and E. stolonifera, E. bicyclis (Kjellman) Setchell, and I. foliacea have high potential as antithrombosis agents. Based on components-activity correlation analysis, flavonoids are considered as active anticoagulation components of seaweeds These results suggest that edible seaweeds, especially $S$. confusum, have potential as safe and novel anticoagulants, and $S$. yamade and $H$. fusiforme Okamura could be used as a thrombin-specific and coagulation factor-specific inhibitors.
\end{abstract}

Key words : Edible seaweeds, anticoagulation activity, activated partial thromboplastin time, prothrombin time, thrombin time, Sargassum confusum

\section{서 론}

해양은 지구 표면적의 약 $70 \%$ 를 차지하며, 지구 상 생물종 의 $80 \%$ 이상이 생존하는 주요 서식처이다. 또한 해양은 지구 온도조절 및 모든 생명체의 생존을 지탱해주는 중요한 역할을 수행하고 있다. 인류는 수많은 해양생물 종들을 식용, 약용 및 화장품 등의 다양한 용도로 이용하여 왔다. 한편 한국은 삼면이 바다로 둘러싸여 다양한 해산물들을 쉽게 얻을 수 있 으며, 특히 해조류의 경우 중국, 필리핀, 일본에 이어 세계 4 위 의 생산국이다[9]. 김, 미역, 다시마, 청각, 파래, 톳 등의 다양한 해조류는 단백질과 미네랄이 풍부하여 유용 식용자원으로 이 용되어 왔으며, 건제품, 염장품 및 조미품 등으로 직접 이용하 거나 또는 다른 식품의 부재료로 첨가되기도 하며, 최근에는 해조류의 다양한 건강기능성이 알려지면서 환, 정, 드링크 등 의 가공제품으로 출시되고 있다[6,22]. 과거 해조류에 대한 연 구는 주로 양식, 수확 및 저장에 관한 연구가 대부분이었으나 [9], 최근에는 해조류의 중금속 제거 활성[2], 고지혈증 예방[6]

\footnotetext{
*Corresponding author

Tel : +82-54-820-5491, Fax : +82-54-820-7804

E-mail : hysohn@andong.ac.kr
}

및 angiotensin-I 전환효소 저해에 의한 항고혈압 활성[17], 항 돌연변이[13] 및 항암 활성[14], 항염증[7], 항산화[10,22], 항적 조[5], 항균 활성 $[8,11,18,19,20]$ 및 항응고 활성 $[15,21,30]$ 등의 다양한 생리활성이 보고되고 있다. 따라서 향후 식품, 의약품 및 화장품 분야에서의 해조류의 이용은 폭발적으로 증가되리 라 판단된다.

한편, 인구의 고령화와 현대사회의 고도화에 따라 혈전성 질환이 빠르게 증가되고 있으며 이러한 혈전성 질환에 해조 류가 긍정적으로 작용함이 알려져 있다[21]. 혈전증은 외인 성 또는 내인성 요인에 의한 혈전의 과다생성으로 인해 혈액 순환이 비정상적인 상태를 말하며, 혈액순환 장해, 혈행속도 감소, 혈액점도 이상 및 이로 인한 조직 기관의 손상 등의 문 제점을 야기하며 $[1,4]$, 특히 심혈관 및 뇌혈관 이상의 경우 생 명이 위협받기도 한다[3,12]. 본 연구팀에서는 와파린, 헤파 린, 아스피린 등 기존 항혈전제가 가진 경구투여 불가, 사용 범위 제한 및 위장장해 등의 문제점을 보완할 수 있는 안전 성이 우수한 신규의 항혈전제 개발을 목표로 장기간 연구하 여 왔으며, 약용 및 야생식물[26,28,29], 산채류[16], 국내 자 생곤충[24], 기능성 쌀[27], 천연 향신료[25] 및 전통주[23] 등 으로부터 항혈전제 및 트롬빈 직접 저해제를 선별, 개발하여 
왔다. 따라서 본 연구에서는 안전성이 확보된 식용자원인 해 조류의 항혈전 활성 평가 및 신규의 항혈전제 개발 가능성을 검토하고자 하였다. 대부분의 기존 연구가 해조류의 열수 및 냉수 추출물을 조제하고, fucoidan과 같은 고분자 해조다당 류를 대상으로 내인성 경로에 의한 항혈전 활성을 평가한 것 $[15,21,3]$ 과는 달리, 본 연구에서는 해조류의 메탄올 추출물 을 조제하고 저분자의 지용성 물질을 대상으로 thrombin time (TT), prothrombin time (PT), activated partial thromboplastin time $(\mathrm{aPTT})$ 을 평가하였다. 그 결과 수종의 갈조류 에서 매우 강력한 항혈전 활성을 확인하고, 유의성 있는 결
과를 얻었기에 이에 보고하는 바이다.

\section{재료 및 방법}

실험재료 및 시료의 조제

본 실험에 사용된 해조류들은 갈조류 17 종, 홍조류 11 종 및 녹조류 7종의 35종으로, 그 중 33종은 2003년 6월에서 2008년 9월 사이에 부산, 경남, 경북 및 전남에서, 포도송이해초 및 코토니 2종은 각각 2008년 1월 Vietnam 및 2008년 9월 Indonesia에서 구입하여 시료로 사용하였다(Table 1). 해조류

Table 1. The list of algae used in this study

\begin{tabular}{|c|c|c|c|}
\hline Scientific name & Korean name & Extraction (\%) & Sources \\
\hline \multicolumn{4}{|l|}{ Phaeophyta } \\
\hline Colpomenia sinuosa & Bulregi-mal & 7.66 & Deabyun, Pusan $(2007,02)$ \\
\hline Costaria costata & Saemiyeuk & 4.76 & Kijang, Pusan $(2006,04)$ \\
\hline Ecklonia cava & Gamtae & 8.34 & Kijang, Pusan $(2008,04)$ \\
\hline Ecklonia stolonifera & Gompi & 3.43 & Youngdo, Pusan $(2008,08)$ \\
\hline Eisenia bicyclis (Kjellman) Setchell & Daehwang & 11.10 & Ulleung, Kyungpook (2006, 08) \\
\hline Hixikia fusiforme Okamura & Tot & 4.39 & Wando, Chonnam $(2008,03)$ \\
\hline Ishige foliacea & Nueppae & 2.71 & Kijang, Pusan $(2003,10)$ \\
\hline Ishige okamurai & Pae & 4.29 & Kijang, Pusan $(2003,10)$ \\
\hline Laminaria japonica Areschong & Dasima & 3.34 & Songjung, Pusan $(2008,05)$ \\
\hline Sargassum confusum & Alsongi-Mojaban & 10.53 & Songjung, Pusan $(2004,02)$ \\
\hline Sargassum fulvellum & Mojaban & 6.07 & Sinan, Chonnam $(2006,03)$ \\
\hline Sargassum hemiphyllum & Jakip-Mojaban & 7.11 & Geoje Island, Kyungnam (2008. 04) \\
\hline Sargassum horneri & Gengsengi-Mojaban & 6.28 & Pohang, Kyungpook $(2007,02)$ \\
\hline Sargassum thumbergii & Jichungei & 4.67 & Geoje Island, Kyungnam (2008. 04) \\
\hline Sargassum yamade & Yamada-Mojaban & 7.54 & Geoje Island, Kyungnam (2008) \\
\hline Scytosiphon lomentaria & Gorimae & 7.67 & Songjung, Pusan $(2005,02)$ \\
\hline Undaria pinnatifida & Miyeuk & 6.67 & Dongbak, Pusan $(2006,01)$ \\
\hline \multicolumn{4}{|l|}{ Rhodophyta } \\
\hline Chondrus ocellatus Holmes & Jindubal & 7.35 & Chungsapo, Pusan $(2008,05)$ \\
\hline Corallina pilulifera & Jaeungusel-Sanhomal & 1.83 & Wando, Chonnam $(2008,03)$ \\
\hline Gigartina tenella Harvey & Dolgasari & 5.51 & Deabyun, Pusan $(2005,03)$ \\
\hline Grateloupia elliptica Holmes & Cham-Dovak & 2.50 & Deabyun, Pusan $(2008,03)$ \\
\hline Halymeniopsis dilatata & Eulruk-Dovak & 4.89 & Pohang, Kyungpook $(2007,02)$ \\
\hline Kappaphycus alvarezii & Kotoni & 3.97 & Kanmun jawa, Indonesia (2008. 09) \\
\hline Lomentaria catenata Harvey & Madi-Jalroki & 7.11 & Deabyun, Pusan $(2005,03)$ \\
\hline Pachymeniopsis elliptica Yamada & Dovak & 4.52 & Deabyun, Pusan $(2003,06)$ \\
\hline Pachymeniopsis lanceolata & Gae-Dovak & 6.29 & Pohang, Kyungpook $(2007,02)$ \\
\hline Porphyra yezoensis Ueda & Bansamuni-Kim & 7.19 & Chungsapo, Pusan $(2004,03)$ \\
\hline Zanardinula cornea & Bulkeun-Gamaksal & 6.57 & Chungsapo, Pusan $(2007,03)$ \\
\hline \multicolumn{4}{|l|}{ Chlorophyta } \\
\hline Capsosiphon fulvescens & Maesengi & 5.43 & Kijang, Pusan $(2008,12)$ \\
\hline Caulerpa racemosa & Podosongi-Heacho & 3.68 & Khanh Hoa, Vietnam $(2008,01)$ \\
\hline Codium fragile (Suringar) Hariot & Chungkak & 6.29 & Samchunpo, Kyungnam $(2008,08)$ \\
\hline Enteromorpha compressa & Napjak-Parae & 5.49 & Songjung, Pusan $(2004,02)$ \\
\hline Enteromorpha linza & Ip-Parae & 5.24 & Chungsapo, Pusan $(2008,05)$ \\
\hline Ulva pertusa & Gumunggal-Parae & 3.58 & Chungsapo, Pusan $(2008,05)$ \\
\hline Zostera marina & Jalpi & 13.19 & Deabyun, Pusan $(2008,03)$ \\
\hline
\end{tabular}


Table 2. In-vitro anticoagulation activity of 35 different algae

\begin{tabular}{|c|c|c|c|}
\hline \multirow{2}{*}{ Scientific name } & \multicolumn{3}{|c|}{ Coagulation (x control) } \\
\hline & TT & PT & $\mathrm{aPTT}$ \\
\hline \multicolumn{4}{|l|}{ Phaeophyta } \\
\hline Colpomenia sinuosa & $1.10 \pm 0.02$ & $0.91 \pm 0.01$ & $2.66 \pm 0.31$ \\
\hline Costaria costata & $0.89 \pm 0.01$ & $0.96 \pm 0.01$ & $1.45 \pm 0.12$ \\
\hline Ecklonia cava & $>14.0$ & $>14.0$ & $>14.0$ \\
\hline Ecklonia stolonifera & $>14.0$ & $>14.0$ & $>14.0$ \\
\hline Eisenia bicyclis (Kjellman) Setchell & $>14.0$ & $>14.0$ & $>14.0$ \\
\hline Hixikia fusiforme Okamura & $1.59 \pm 0.00$ & $1.00 \pm 0.00$ & $>14.0$ \\
\hline Ishige foliacea & $>14.0$ & $>14.0$ & $>14.0$ \\
\hline Ishige okamurai & $>14.0$ & $>14.0$ & $>14.0$ \\
\hline Laminaria japonica Areschong & $1.23 \pm 0.03$ & $0.97 \pm 0.01$ & $1.96 \pm 0.17$ \\
\hline Sargassum confusum & $>14.0$ & $>14.0$ & $>14.0$ \\
\hline Sargassum fulvellum & $1.00 \pm 0.06$ & $0.84 \pm 0.03$ & $2.43 \pm 0.27$ \\
\hline Sargassum hemiphyllum & $1.12 \pm 0.00$ & $0.93 \pm 0.02$ & $3.3 \pm 0.31$ \\
\hline Sargassum horneri & $1.23 \pm 0.07$ & $0.92 \pm 0.01$ & $3.14 \pm 0.30$ \\
\hline Sargassum thunbergii & $1.11 \pm 0.04$ & $0.99 \pm 0.02$ & $2.38 \pm 0.25$ \\
\hline Sargassum yamade & $>14.0$ & $1.13 \pm 0.08$ & $2.89 \pm 0.27$ \\
\hline Scytosiphon lomentaria & $0.88 \pm 0.01$ & $1.06 \pm 0.03$ & $2.03 \pm 0.18$ \\
\hline Undaria pinnatifida & $0.91 \pm 0.01$ & $1.12 \pm 0.02$ & $1.79 \pm 0.09$ \\
\hline \multicolumn{4}{|l|}{ Rhodophyta } \\
\hline Chondrus ocellatus Holmes & $0.93 \pm 0.10$ & $1.06 \pm 0.00$ & $1.57 \pm 0.11$ \\
\hline Corallina pilulifera & $1.10 \pm 0.01$ & $1.01 \pm 0.02$ & $0.94 \pm 0.15$ \\
\hline Gigartina tenella Harvey & $1.02 \pm 0.14$ & $1.04 \pm 0.01$ & $1.63 \pm 0.27$ \\
\hline Grateloupia elliptica Holmes & $1.18 \pm 0.09$ & $1.03 \pm 0.03$ & $1.54 \pm 0.18$ \\
\hline Halymeniopsis dilatata & $1.03 \pm 0.12$ & $1.11 \pm 0.01$ & $1.19 \pm 0.07$ \\
\hline Kappaphycus alvarezii & $0.92 \pm 0.07$ & $1.00 \pm 0.01$ & $2.08 \pm 0.10$ \\
\hline Lomentaria catenata Harvey & $0.92 \pm 0.02$ & $1.11 \pm 0.02$ & $1.45 \pm 0.08$ \\
\hline Pachymeniopsis elliptica Yamada & $1.12 \pm 0.01$ & $1.03 \pm 0.01$ & $1.28 \pm 0.05$ \\
\hline Pachymeniopsis lanceolata & $0.96 \pm 0.05$ & $1.04 \pm 0.02$ & $1.39 \pm 0.07$ \\
\hline Porphyra yezoensis Ueda & $0.83 \pm 0.09$ & $1.09 \pm 0.01$ & $1.52 \pm 0.09$ \\
\hline Zanardinula cornea & $1.00 \pm 0.02$ & $0.92 \pm 0.03$ & $1.41 \pm 0.11$ \\
\hline \multicolumn{4}{|l|}{ Chlorophyta } \\
\hline Capsosiphon fulvescens & $1.20 \pm 0.13$ & $0.98 \pm 0.01$ & $1.34 \pm 0.19$ \\
\hline Caulerpa racemosa & $2.25 \pm 0.01$ & $1.06 \pm 0.01$ & $2.81 \pm 0.22$ \\
\hline Codium fragile (Suringar) Hariot & $1.17 \pm 0.01$ & $0.94 \pm 0.02$ & $2.32 \pm 0.18$ \\
\hline Enteromorpha compressa & $1.09 \pm 0.03$ & $0.94 \pm 0.01$ & $1.26 \pm 0.06$ \\
\hline Enteromorpha linza & $1.76 \pm 0.00$ & $1.00 \pm 0.01$ & $3.38 \pm 0.31$ \\
\hline Ulva pertusa & $1.06 \pm 0.07$ & $1.01 \pm 0.01$ & $2.59 \pm 0.12$ \\
\hline Zostera marina & $1.19 \pm 0.01$ & $0.95 \pm 0.02$ & $1.73 \pm 0.07$ \\
\hline \multicolumn{4}{|l|}{ Positive control } \\
\hline Heparin $(1.5 \mu \mathrm{g} / \mathrm{ml})$ & $>14.0$ & $1.12 \pm 0.01$ & $1.27 \pm 0.02$ \\
\hline Aspirin $(1.5 \mathrm{mg} / \mathrm{ml})$ & $2.60 \pm 0.14$ & $1.06 \pm 0.03$ & $1.01 \pm 0.02$ \\
\hline
\end{tabular}

The concentrations of algae extract, heparin and aspirin as positive controls used were $5 \mathrm{mg} / \mathrm{ml}, 1.5 \mu \mathrm{g} / \mathrm{ml}$ and $1.5 \mathrm{mg} / \mathrm{ml}$ respectively. Data are reported as relative clotting time based on solvent control (x control). The thrombin time (TT), prothrombin time (PT) and activated partial thromboplastin time (aPTT) of solvent control (dimethylsulfoxide) were $32.5 \mathrm{sec}, 18.5 \mathrm{sec}$ and 39.5 sec, respectively.

들은 부경대학교에서 동정, 확인하였으며, 각각의 시료는 현 재 부경대학교 생물공학과에 보관되어 있다. 채취한 해조류들 은 이물질을 제거하고 수돗물로 세척한 후 실온에서 음건하였
다. 건조 해조류들은 믹서기로 분쇄 후 $-20^{\circ} \mathrm{C}$ 에서 사용 전까지 보관하였다. 메탄올 추출물은 건조분말 해조류에 10 배 부피의 메탄올을 가한 후 상온에서 2 일 추출하였으며, 이를 4 회 반복 
한 후 추출액을 모아 감압 농축하여 분말로 제조하였다. 사용 한 해조류의 상세정보는 Table 1에 나타내었다. 추출물은 DMSO (dimethylsulfoxide)에 녹인 후 적당한 농도로 희석하 여 coagulation parameter인 TT, PT 및 aPTT를 측정하였으며, 활성물질 탐색을 위해 총 flavonoid, 총 polyphenol, 총당 및 환원당 함량을 측정하였다. 사용한 인간혈장은 최근 1 개월 동 안 약물투여를 받지 않은 지원자의 전혈로부터 조제하였으며, 채혈 후 $4^{\circ} \mathrm{C}$ 에서 $5,000 \times g$ 로 5 분 동안 원심분리하여 혈장을 분리하고 냉동보관 하였으며, 필요시 상온에서 해동하여 사용 하였다. PT와 aPTT분석에는 MD Pacific Hemostasis (Tianjin MD Pacific Co., China)의 분석시약 및 표준혈장(MD Pacific Co., China )을 사용하여 측정하였다.

\section{항혈전 활성}

항혈전 활성은 해조류 시료들의 TT, PT및 $\mathrm{aPTT}$ 를 측정하 여 평가하였으며, 기존의 보고한 방법과 동일하게 Amelung coagulometer KC-1A (Tokyo, Japan)를 이용하여 혈액응고시 간을 측정하여 평가하였다[26]. 시료 대조군으로는 아스피린 과 헤파린(Sigma Co., USA)을, 용매 대조군으로는 DMSO를 사용하였다. 시료의 항혈전 활성은, 해조류 시료의 TT, PT및 $\mathrm{aPTT}$ 를 각각 3 회 이상 반복한 실험의 평균치를 용매 대조구 인 DMSO의 TT, PT 및 $\mathrm{aPTT}$ 평균치의 비로 각각 나타내었다.

\section{기타 분석}

해조류 시료의 총 flavonoid의 함량 측정은 기존의 보고한 방법[27]에 따라 측정하였으며, 각각의 시료를 18 시간 메탄올 교반 추출하고 여과한 추출 검액 $400 \mu 1$ 에 $90 \%$ diethylene gly$\operatorname{col} 4 \mathrm{ml}$ 를 첨가하고 다시 $1 \mathrm{~N} \mathrm{NaOH} 40 \mu 1$ 를 넣고 $37^{\circ} \mathrm{C}$ 에서 1시간 반응 후 $420 \mathrm{~nm}$ 에서 흡광도를 측정하였다. 표준시약으 로는 rutin을 사용하였다. 총 polyphenol 함량은 추출 검액 400 $\mu \mathrm{l}$ 에 $50 \mu \mathrm{l}$ 의 Folin-ciocalteau, $100 \mu \mathrm{l}$ 의 $\mathrm{Na}_{2} \mathrm{CO}_{3}$ 포화용액을 넣 고 실온에서 1 시간 방치한 후 $725 \mathrm{~nm}$ 에서 흡광도를 측정하였 다[27]. 표준시약으로는 tannic acid를 사용하였다. 총당 정량은 시료 $100 \mu 1$ 를 $5 \%$ 페놀용액 $300 \mu \mathrm{l}$ 및 진한황산 $1.5 \mathrm{ml}$ 를 가하여 실온에서 30 분간 반응시킨 후, $490 \mathrm{~nm}$ 에서 흡광도를 측정하여 결정하였으며, sucrose를 이용하여 작성한 표준검량선에 의해 계산하였다. 환원당 정량은 시료용액 $200 \mu \mathrm{l}$ 를 dnitrosalicylic acid reagent $600 \mu \mathrm{ll}$ 와 잘 혼합한 후 $100^{\circ} \mathrm{C}$ 에서 10 분간 중탕하였 고, 실온에서 방냉 후, $546 \mathrm{~nm}$ 에서 흡광도를 측정하였으며, glucose를 이용하여 작성한 표준검량선에 의해 계산하였다[23].

\section{통계분석}

실험 결과는 SPSS 18.0 버전을 사용하여 mean $\pm \mathrm{SD}$ 로 나타 내었으며, 각 군간의 차이는 ANOVA Tukey LSD 통계처리방 법으로 통계적 유의성 검정을 조사하였다. 유의수준은 $p<0.05$ 로 하였다. 항혈전 활성과 추출물 성분과의 상관관계 검토는
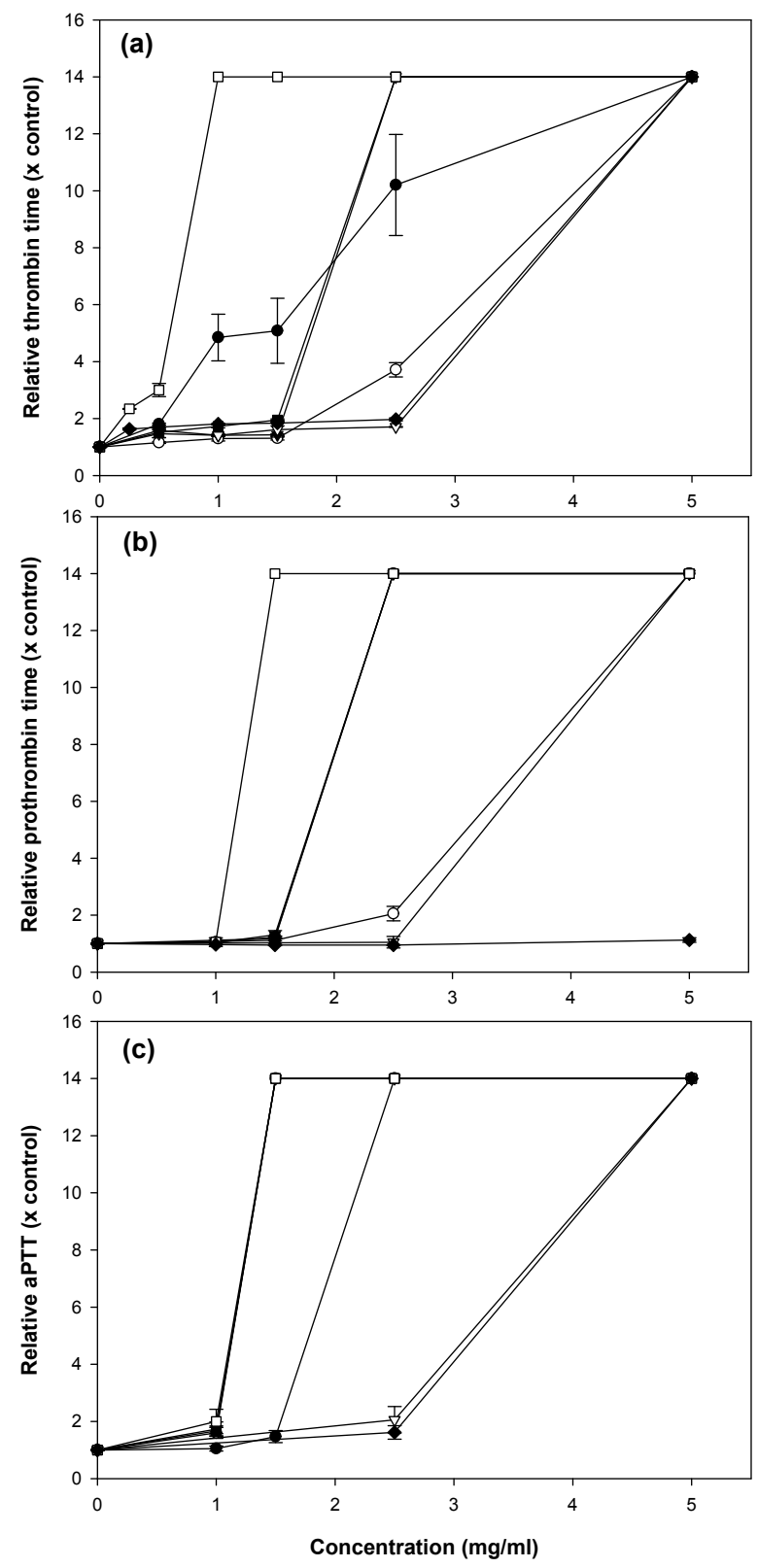

Fig. 1. Comparison of anticoagulation activity of the selected algae. (a) Inhibition of thrombin and (b) Inhibition of prothrombin (•: Ecklonia cava, $\bigcirc$ : Ecklonia stolonifera, $\mathbf{v}$ : Eisenia bicyclis (Kjellman) Setchell, $\nabla$ : Ishige okamurai, $\mathbf{n}$ Ishige foliacea, $\square$ : Sargassum confusum, and $\bullet$ : Sargassum yamade), (c) Inhibition of coagulation factors (•: Ecklonia cava, $\bigcirc$ : Ecklonia stolonifera, $\mathbf{\nabla}$ : Eisenia bicyclis (Kjellman) Setchell, $\nabla$ : Ishige okamurai, $\mathbf{n}$ : Ishige foliacea, $\square$ : Sargassum confusum, and $\downarrow$ : Hixikia fusiforme Okamura).

SigmaPlot 2001 (Ver 7.0)의 linear regression을 이용하였다.

\section{결과 및 고찰}

35 종 해조류는 의 메탄올 추출효율은 $1.83 \%$ (작은구슬산호 
말) $13.19 \%$ (잘피) 로 다양하였으며, 평균 추출율은 $5.92 \pm 2.43 \%$ 였다(Table 1). 17 종 갈조류의 평균 추출율은 $6.29 \pm 2.42 \%, 11$ 종 홍조류의 평균 추출율은 $5.25 \pm 1.90 \%$ 및 7종 녹조류의 평균 추 출율은 $6.19 \pm 3.27 \%$ 로 거의 유사하였다. 그러나, 잘피, 대황, 알 송이모자반, 감태 등은 $8 \%$ 이상의 높은 추출효율을 나타내었 다. 이러한 추출율은 해조류의 채취시기와 채취장소에 따라 차이가 나리라 예상되므로 각각의 해조류의 특성으로 볼 수는 없으나, 유효활성물질의 경제성 평가 등의 기본자료로 이용될 것이다. 조제된 메탄올 추출물을 대상으로 TT, PT 및 $\mathrm{aPTT}$ 를 조사한 결과는 Table 2에 나타내었다. TT는 혈전생성에 있어 가장 중요한 트롬빈 활성화에 의해 피브리노젠이 피브린으로 전환되어 나타나는 혈전생성까지의 시간을 나타내는 수치로,
본 실험에서는 용매대조구로 사용된 DMSO 첨가구에서 평균 32.5초를 나타내었다. PT는 주로 외인계 응고 인자의 결핍 및 이상을 검출하는 검사로, 혈장에 조직 트롬보플라스틴과 칼슘 을 첨가한 경우 피브린으로 석출될 때까지의 시간을 말하며 본 실험에서 시료 무첨가구는 18.5 초를 나타내었다. 한편 $\mathrm{aPTT}$ 는 혈장내 응고 인자의 결핍을 측정하는 방법으로 수술 전의 환자 및 출혈성 소인의 일반검사에서 이용되고 있으며, 본 실험에서 시료 무첨가구는 39.5초를 나타내었다. 먼저 활성 대조구로 사용된 아스피린은 $1.5 \mathrm{mg} / \mathrm{ml}$ 농도에서 용매 대조 구에 비해 약 2.6배의 증가된 TT 값을 나타내었고, PT 및 aPTT 에는 거의 영향을 나타내지 않았다. 헤파린은 $1.5 \mathrm{\mu g} / \mathrm{ml}$ 농도 에서 용매 대조구의 14 배 이상의 연장된 TT 값을 나타내어

Table 3. The contents of total flavonoid, total polyphenol, total sugar and reducing sugar of methanol extracts prepared from 35 different algae

\begin{tabular}{|c|c|c|c|c|}
\hline \multirow{2}{*}{ Scientific name } & \multicolumn{4}{|c|}{ Content (mg/g) } \\
\hline & Total flavonoid & Total polyphenol & Total sugar & Reducing Sugar \\
\hline \multicolumn{5}{|l|}{ Phaeophyta } \\
\hline Colpomenia sinuosa & $1.38 \pm 0.55$ & $4.09 \pm 0.26$ & $33.50 \pm 2.36$ & $14.62 \pm 0.11$ \\
\hline Costaria costata & $2.31 \pm 0.11$ & $5.48 \pm 0.11$ & $38.11 \pm 0.56$ & $13.99 \pm 0.11$ \\
\hline Ecklonia cava & $52.10 \pm 2.75$ & $148.01 \pm 1.46$ & $45.17 \pm 0.56$ & $35.38 \pm 2.66$ \\
\hline Ecklonia stolonifera & $41.29 \pm 0.00$ & $144.14 \pm 1.46$ & $44.57 \pm 0.00$ & $33.03 \pm 1.55$ \\
\hline Eisenia bicyclis (Kjellman) Setchell & $55.68 \pm 1.65$ & $189.03 \pm 0.36$ & $82.15 \pm 1.41$ & $43.53 \pm 3.77$ \\
\hline Hixikia fusiforme Okamura & $9.16 \pm 0.33$ & $19.05 \pm 1.50$ & $66.99 \pm 1.80$ & $16.65 \pm 0.55$ \\
\hline Ishige foliacea & $19.82 \pm 1.32$ & $74.62 \pm 3.83$ & $81.39 \pm 3.94$ & $46.28 \pm 2.11$ \\
\hline Ishige okamurai & $15.77 \pm 0.22$ & $36.40 \pm 1.46$ & $76.77 \pm 0.56$ & $35.15 \pm 1.00$ \\
\hline Laminaria japonica Areschong & $6.44 \pm 1.54$ & $6.15 \pm 0.40$ & $68.83 \pm 3.94$ & $10.85 \pm 0.11$ \\
\hline Sargassum confusum & $15.31 \pm 0.44$ & $34.44 \pm 2.48$ & $32.54 \pm 0.79$ & $26.21 \pm 0.78$ \\
\hline Sargassum fulvellum & $5.35 \pm 0.44$ & $37.28 \pm 2.12$ & $71.60 \pm 4.72$ & $18.46 \pm 1.55$ \\
\hline Sargassum hemiphyllum & $2.55 \pm 0.44$ & $6.77 \pm 0.26$ & $29.12 \pm 0.90$ & $12.74 \pm 0.78$ \\
\hline Sargassum horneri & $3.64 \pm 0.88$ & $6.26 \pm 0.04$ & $42.98 \pm 2.25$ & $14.07 \pm 0.22$ \\
\hline Sargassum thunbergii & $4.34 \pm 2.09$ & $8.22 \pm 0.04$ & $45.51 \pm 2.70$ & $27.31 \pm 1.44$ \\
\hline Sargassum yamade & $12.74 \pm 0.99$ & $79.01 \pm 0.91$ & $51.71 \pm 1.57$ & $23.32 \pm 0.44$ \\
\hline Scytosiphon lomentaria & $2.39 \pm 0.44$ & $6.67 \pm 0.11$ & $60.68 \pm 0.84$ & $15.32 \pm 0.00$ \\
\hline Undaria pinnatifida & $1.85 \pm 0.11$ & $7.44 \pm 0.26$ & $59.68 \pm 4.22$ & $10.85 \pm 0.78$ \\
\hline \multicolumn{5}{|l|}{ Rhodophyta } \\
\hline Chondrus ocellatus Holmes & $0.81 \pm 0.02$ & $4.44 \pm 0.20$ & $272.25 \pm 7.42$ & $5.76 \pm 0.00$ \\
\hline Corallina pilulifera & $1.86 \pm 0.09$ & $4.19 \pm 0.05$ & $66.44 \pm 2.25$ & $7.33 \pm 0.00$ \\
\hline Gigartina tenella Harvey & $0.89 \pm 0.00$ & $11.78 \pm 0.40$ & $74.00 \pm 1.41$ & $5.13 \pm 0.00$ \\
\hline Grateloupia elliptica Holmes & $1.27 \pm 0.07$ & $5.67 \pm 0.18$ & $76.19 \pm 6.47$ & $8.42 \pm 0.22$ \\
\hline Halymeniopsis dilatata & $1.29 \pm 0.08$ & $4.07 \pm 0.47$ & $68.83 \pm 6.19$ & $11.32 \pm 0.78$ \\
\hline Kappaphycus alvarezii & $0.99 \pm 0.01$ & $5.79 \pm 0.05$ & $57.30 \pm 1.97$ & $7.01 \pm 0.66$ \\
\hline Lomentaria catenata Harvey & $1.29 \pm 0.43$ & $4.11 \pm 0.05$ & $60.28 \pm 0.28$ & $6.62 \pm 0.55$ \\
\hline Pachymeniopsis elliptica Yamada & $0.79 \pm 0.03$ & $4.16 \pm 0.24$ & $51.16 \pm 0.34$ & $5.60 \pm 0.00$ \\
\hline Pachymeniopsis lanceolata & $0.98 \pm 0.01$ & $4.97 \pm 0.04$ & $64.06 \pm 5.62$ & $7.71 \pm 0.00$ \\
\hline Porphyra yezoensis Ueda & $3.89 \pm 0.43$ & $7.46 \pm 0.75$ & $61.87 \pm 8.16$ & $12.26 \pm 1.00$ \\
\hline Zanardinula cornea & $0.71 \pm 0.01$ & $2.30 \pm 0.09$ & $72.41 \pm 2.25$ & $6.00 \pm 0.78$ \\
\hline \multicolumn{5}{|l|}{ Chlorophyta } \\
\hline Capsosiphon fulvescens & $4.96 \pm 1.21$ & $15.87 \pm 0.58$ & $97.21 \pm 1.12$ & $19.95 \pm 1.22$ \\
\hline Caulerpa racemosa & $2.70 \pm 0.88$ & $6.03 \pm 0.22$ & $156.53 \pm 5.06$ & $20.65 \pm 0.66$ \\
\hline Codium fragile (Suringar) Hariot & $4.10 \pm 1.32$ & $10.69 \pm 0.40$ & $91.73 \pm 0.34$ & $14.46 \pm 1.00$ \\
\hline Enteromorpha compressa & $4.65 \pm 0.55$ & $10.23 \pm 0.77$ & $257.55 \pm 8.72$ & $41.97 \pm 0.44$ \\
\hline Enteromorpha linza & $3.95 \pm 1.10$ & $10.26 \pm 0.58$ & $222.75 \pm 1.69$ & $33.11 \pm 0.78$ \\
\hline Ulva pertusa & $5.04 \pm 0.44$ & $7.47 \pm 0.66$ & $58.00 \pm 0.56$ & $13.44 \pm 0.00$ \\
\hline Zostera marina & $8.46 \pm 0.55$ & $22.66 \pm 0.91$ & $373.89 \pm 10.41$ & $50.20 \pm 2.11$ \\
\hline
\end{tabular}


우수한 항트롬빈 활성을 나타내었다(Table 2). 그러나 헤파린 역시 PT 및 aPTT 값의 변화를 거의 나타내지 않아, 아스피린 과 헤파린은 트롬빈의 저해를 통해 항혈전 활성을 나타냄을 확인하였다(Table 2). 한편 해조류 시료 농도 $5 \mathrm{mg} / \mathrm{ml}$ 에서 $\mathrm{TT}$ 를 측정한 결과, 갈조류 17 종류 중 감태, 곰피, 대황, 넓패, 패, 알송이모자반 및 야마다모자반의 7종에서 14 배 이상 연장 된 TT 값을 나타내었다. 반면 홍조류와 녹조류에서는 트롬빈 저해활성이 인정되지 않았다(Table 2). PT 측정 결과, 트롬빈 저해활성이 나타난 7종 중 야마다모자반을 제외한 6 종에서 강력한 프로트롬빈 저해활성이 나타났다. aPTT 측정에서는, 프로트롬빈 저해활성이 나타난 6종의 시료(알송이모자반, 감 태, 곰피, 대황, 넓패, 및 패) 및 톳에서 14 배 이상 연장된 aPTT 값을 나타내어 내인성 유래 혈전생성을 강력하게 억제함을 확인하였다. 그 외 모자반(모자반, 괭생이모자반 및 야마다모 자반), 지충이, 청각, 파래(잎파래 및 구멍갈파래) 등은 2.5 3.4 배 이상의 연장된 aPTT 값을 나타내어 기존 보고와 유사하였 다[15,30]. 그러나 본 실험에서는 14 배 이상의 강력한 항응고 활성을 나타내는 감태, 곰피, 대황, 넓패, 패, 알송이모자반,
야마다모자반 및 톳의 8 종 갈조류를 선별하였으며, 감태, 패, 톳을 제외한 5종에서는 트롬빈 저해활성이 보고된 바 없다.

기존의 해조류 물 추출물의 경우 홍조류가 갈조류 및 녹조 류보다 상대적으로 우수한 aPTT 연장활성을 나타내는 것으로 보고[30]되어 있으나, 본 연구에서는 갈조류에서 더욱 강력한 항혈전 활성이 나타나는 것이 특이하였으며, 특히 톳과 야마 다모자반은 다른 6 종과는 달리 각각 aPTT 및 TT 값만을 14 배 이상 연장시켰다(Table 2). 이러한 결과는 다양한 혈전생성 경 로 중에서 톳은 내인성 경로의 혈액응고인자 저해를 통해, 야 마다모자반은 트롬빈 저해를 통해 항응고 활성을 나타냄을 의미한다. 현재까지 갈조류의 항혈전 성분으로 알려진 물질은 alginic acid와 fucoidan $[15,21,30]$ 과 같은 수용성의 고분자 다 당류이나, 본 실험에서는 지용성, 저분자 물질들을 대상으로 시료를 조제하였기 때문에 alginic acid 및 fucoidan 에 의한 항혈전 활성은 아닌 것으로 판단된다. 실제 고분자 및 저분자 alginic acid 및 fucoidan (Sigma Co., USA)의 경우 $5 \mathrm{mg} / \mathrm{ml}$ 농도까지는 트롬빈의 직접저해는 나타나지 않았다(results not shown). 따라서 본 연구의 갈조류 항혈전 활성물질은 기
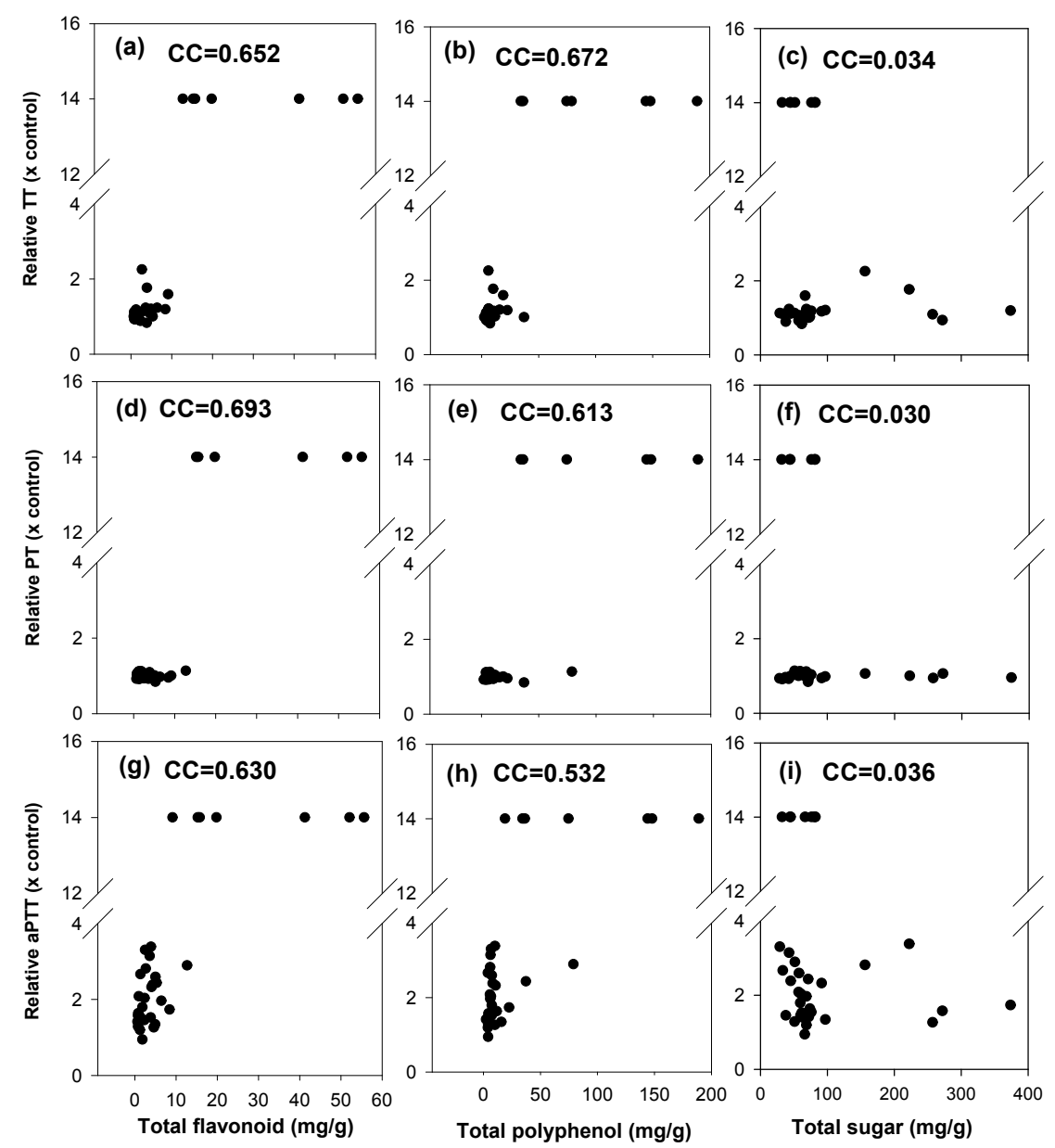

Fig. 2. The relationship between the contents of total flavonoid ( $a, d$, and g), total polyphenol $(b, e$, and $h)$ and total sugars (c, f, and i) and the anticoagulation activities (TT, PT, and aPTT). CC; correlation coefficient. 
존의 보고된 물질과는 다른 것으로 판단된다.

선별된 8종 해조류 추출물을 대상으로 다양한 농도에서 항 혈전 활성을 평가하였다. 먼저 트롬빈 저해의 경우, 알송이모 자반에서 가장 강력하였으며 $1 \mathrm{mg} / \mathrm{ml}$ 농도에서 대조구의 14 배 이상의 TT 연장, $0.25 \mathrm{mg} / \mathrm{ml}$ 농도에서 2.4 배 TT 연장을 나타내어 아스피린 $(1.5 \mathrm{mg} / \mathrm{ml})$ 이 2.6 배의 TT 연장과 비교할 만 하였다(Fig. 1a). 특히 감태의 경우, 농도 의존적으로 트롬빈 저해가 나타났으며 $1.5 \mathrm{mg} / \mathrm{ml}$ 농도에서 5.1배의 TT 연장을 나타내었다. 대황 및 넓패는 $2.5 \mathrm{mg} / \mathrm{ml}$ 농도에서 14 배 이상의 TT 연장효과를 나타내었으나, 곰피, 패, 야마다모자반의 경우 $2.5 \mathrm{mg} / \mathrm{ml}$ 농도에서 각각 3.7 배, 1.7 배 및 2 배의 약한 TT 연장 효과를 나타내었다. 프로트롬빈 저해의 경우 역시 알송이모자 반에서 가장 강력한 활성이 나타났으며, 대황, 감태, 넓패, 곰 피, 패의 순으로 저해가 강력하였다(Fig. 1b). 야마다모자반의 경우에는 $5 \mathrm{mg} / \mathrm{ml}$ 농도까지 프로트롬빈 저해가 나타나지 않 아 트롬빈 특이적 저해임을 확인하였다. 혈장내 응고인자 저 해를 평가한 경우 곰피, 대황, 넓패 및 알송이모자반은 1.5 $\mathrm{mg} / \mathrm{ml}$ 농도에서 14 배 이상 aPTT를 연장시켰으나, 감태는 2.5 $\mathrm{mg} / \mathrm{ml}$ 농도 이상에서, 톳과 패는 각각 $5 \mathrm{mg} / \mathrm{ml}$ 이상에서 14 배 이상의 연장된 aPTT를 나타내었다(Fig. 1c). 따라서, 내인 성 및 외인성 혈전 생성방지에는 35 종의 해조류 중 곰피, 대황, 넓패 및 알송이모자반이 가장 효율적임을 확인하였다.

35 종 해조류 추출물의 성분분석 결과는 Table 3 에 나타내었 다. 총 flavonoid, 총 polyphenol, 총당 및 환원당 함량은 해조 류 종류에 따라 다양하였으며, 갈조류의 경우 각각 $14.83 \pm 17.7$, $47.82 \pm 59.1,54.78 \pm 17.6$ 및 $23.39 \pm 11.6 \mathrm{mg} / \mathrm{g}$, 홍조류의 경우 각 각 $1.34 \pm 0.9,5.36 \pm 2.5,84.07 \pm 62.8$ 및 $7.56 \pm 2.3 \mathrm{mg} / \mathrm{g}$, 녹조류의 경우 각각 $4.83 \pm 1.8,11.88 \pm 5.6,179.66 \pm 112.2$ 및 $27.68 \pm 14.3$ $\mathrm{mg} / \mathrm{g}$ 을 나타내어 갈조류는 총 flavonoid, 총 polyphenol 함량 이 상대적으로 매우 높으며, 홍조류와 녹조류는 상대적으로 총당 함량이 높음을 알 수 있었다. 각각의 성분과 항혈전 활성 의 상관관계를 검토한 결과(Fig. 2), 총당 함량과 항혈전 활성과 는 무관하였으며 (상관계수 $0.03 \sim 0.036$ ), 항혈전 활성과 가장 뚜렷한 상관관계를 나타낸 것은 총 flavonoid 함량이었다(상관 계수 $0.63 \sim 0.69)$. 부분적으로 총 polyphenol 함량이 높은 경우 TT 값의 연장활성이 우수한 경우가 있었으나, PT 및 $\mathrm{aPTT}$ 와의 상관관계는 낮게 나타났다(상관계수 $0.53 \sim 0.61$ ). 항혈전 활성 이 우수한 8종의 시료는 총 flavonoid 함량 및 총 polyphenol 함량이 상대적으로 매우 높은 특징을 나타내었으며, 각각 $27.73 \pm 18.8$ 및 $90.58 \pm 62.6 \mathrm{mg} / \mathrm{g}$ 의 매우 높은 값을 나타내었다. 따라서 이들은 항혈전 활성뿐만 아니라 항산화 활성도 매우 우수할 것으로 추측된다 $[10,22]$. 현재 추출물의 flavonoid 성분 정제를 진행 중에 있으며, 활성물질의 특성 및 안정성을 검토 중에 있다. 본 결과는 경제적이면서 대량공급이 가능한 해조류 로부터 신규의 안전한 항혈전제 개발이 가능함을 제시하고 있 으며, 톳 및 야마다모자반과 같이 트롬빈 및 혈장내 응고 인자 에 대한 특이 저해제 개발이 가능함을 제시하고 있다.

\section{감사의 글}

본 연구는 중소기업청에서 지원하는 2010년도 산학연공동 기술개발사업 (No. 00041080-1)의 연구수행으로 인한 결과물 임을 밝힙니다.

\section{References}

1. Butenas, S. and S. Mullertz. 2002. Blood coagulation. Biochemistry (Moscow) 67, 3-12.

2. Choi, I. W., S. U. Kim, D. C. Seo, B. H. Kang, B. K. Sohn, Y. S. Rim, J. S. Heo, and J. S. Cho. 2005. Biosorption of heavy metals biomass of seaweeds, Laminaria species, Ecklonia stoIonifera, Gelidium amansii, and Undaria pinnatifida. Korean J. Environ. Agri. 24, 370-378.

3. Eikelboom, J. W., S. L. Zelenkofske, and C. P. Rusconi. 2010. Coagulation factor IXa as a target for treatment and prophylaxis of venous thromboembolism. Arterioscler. Thromb. Vasc. Biol. 30, 382-387.

4. Hsieh, K. H. 1997. Thrombin interaction with fibrin polymerization sites. Thromb. Res. 86, 301-316.

5. Jin, H. J. and D. H. Jin. 2007. Screening of seaweed extracts for algicidal substances using a photosensitization effect. $J$. Korean Fish Soc. 40, 122-127.

6. Joo, D. S., J. K. Lee, Y. S. Choi, S. Y. Cho, Y. K. Je, and J. W. Choi. 2003. Effect of sea tangle oligosaccharide drink on serum and hepatic lipids in rats fed a hyperlipidemic diet. J. Korean Soc. Food Sci. Nutr. 32, 1364-1369.

7. Kang, M. C., J. Y. Lee, R. K. Ko, H. B. Kim, S. H. Hong, and G. O. Kim. 2008. Melanin inhibitory effect and anti-inflammatory effects of Dietyota coriacea extracts derived from adjacent sea of the Jeju island. Korean J. Biotechnol. Bioeng. 23, 311-316.

8. Kang, S. Y., M. J. Oh, and J. A. Shin. 2005. Antimicrobial activity of korean marine algae against fish pathogenic bacteria. J. Fish Pathol. 18, 147-156.

9. Kim, D. W., M. J. Kim, T. S. Shin, S. J. Kim, and B. M. Jung. 2008. Application of hydrogen peroxide on the bacterial control of seaweed Capsosiphon fulvescens (Mesaengi). Korean J. Food Preserv. 15, 169-173.

10. Kim, J. A. and J. M. Lee. 2004. The changes of biologically functional compounds and antioxidant activities in Hizikia fusiformis with drying methods. Korean J. Food Culture 19, 200-208.

11. Kim, J. H., D. S. Lee, C. W. Lim, H. Y. Park, and J. H. Park. 2002. Antibacterial activity of sea-mustard, Laminaria japonica extracts on the cariogenic bacteria, Streptococcus mutans. J. Korean Fish Soc. 35, 191-195.

12. Kim, M. D., S. K. Rhee, and J. H. Seo. 2001. Enhanced production of anticoagulant hirudin in recombinant Saccharomyces cerevisiae by chromosomal $\delta$-integration. J. Biotechnol. 85, 41-48.

13. Kim, S. A., J. Kim, M. K. Woo, C. S. Kwak, and M. S. Lee. Antimutagenic and cytotoxic effects of ethanol extracts from five kinds of seaweeds. J. Korean Soc. Food Sci. Nutr. 34, 
451-459

14. Kong, C. S., Y. R. Um, J. I. Lee, Y. A. Kim, J. S. Lee, and Y. W. Seo. 2008. Inhibition effects of extracts and its solvent fractions isolated from Limonium tetragonum on growth of human cancer cells. J. Biotechnol. Bioeng. 23, 177-182.

15. Koo, J. G., Y. S. Choi, and J. K. Kwak. 2001. Blood-anticoagulation activity of fucoidans from sporophylls of Undaria pinnatifida, Laminaria religiosa, Hizikia fusiforme, and Sargassum fulvellum in Korea. J. Korean Fish Soc. 34, 515-520.

16. Kwon, C. S., Y. S. Kwon, Y. S. Kim, G. S. Kwon, I. N. Jin, G. C. Ryu, and H. Y. Sohn. 2004. Inhibitory activities of edible and medicinal herbs against human thrombin. J. Life Sci. 14, 509-513

17. Lee, H. O., D. S. Kim, J. R. Do, and Y. S. Ko. 1999. Angiotensin-I converting enzyme inhibitory activity of algae. J. Korean Fish Soc. 32, 427-431.

18. Lee, H. S., J. H. Suh, and K. H. Suh. 2000. Preparation of antibacterial agent from seaweed extract and its antibacterial effect. J. Korean Fish Soc. 33, 32-37.

19. Lim, C. W. 2000. Structure and some properties of the antimicrobial compounds in the red alga, Symphylocladia latiuscula. J. Korean Fish Soc. 33, 280-287.

20. Lim, J. H., K. S. Jung, J. S. Lee, E. S. Jung, D. K. Kim, Y. S. Kim, Y. W. Kim, and D. H. Park. 2008. The study on antimicrobial and antifungal activity of the wild seaweeds of Jeju island. J. Soc. Cosmet Sci. Korean 34, 201-207.

21. Nikapitiya, C., M. Zoysa, P. M. Ekanyake, H. J. Park, and J. H. Lee. 2006. Isolation and purification of anticoagulant polysaccharide compound from fermented edible brown seaweed, Laminaria ochotensis. J. Aquaculture 19, 33-39.

22. Oh, J. K., Y. O. Shin, H. S. Sohn, and R. M. Seo. 2003. Effect of functional food including seaweeds extracts supplementation on hematological variables and antioxidant system. Korean J. Physical Education 42, 895-903.

23. Ryu, H. Y., E. J. Kum, K. H. Bae, Y. K. Kim, I. S. Kwun, and H. Y. Sohn. 2007. Evaluation for the antimicrobial, antioxidant and anti-thrombosis activity of Korean traditional liquors. Korean J. Microbiol. Biotechnol. 35, 238-244.

24. Ryu, H. Y., J. C. Heo, J. S. Hwang, S. W. Kang, C. Y. Yun, S. H. Lee, and H. Y. Sohn. 2008. Screening of thrombin inhibitor and its DPPH radical scavenging activity from wild insects. J. Life Sci. 18, 363-368.

25. Ryu, H. Y., K. H. Bae, E. J. Kum, S. J. Park, B. H. Lee, and H. Y. Sohn. 2007. Evaluation of antimicrobial, antioxidant and antithrombosis activity of natural spices for fresh-cut yam. J. Life Sci. 17, 652-657.

26. Ryu, H. Y., S. M. Ahn, J. S. Kim, and H. Y. Sohn. 2010. Evaluation of in-vitro anticoagulation activity of 33 different medicinal herbs. J. Life Sci. 20, 922-928.

27. Sohn, H. Y., C. S. Kwon, K. H. Son, G. S. Kwon, W. S. Kwon, H. Y. Ryu, and E. J. Kum. 2005. Antithrombosis and antioxidant activity of methanol extract from different brands of rice. J. Korean Soc. Food Sci. Nutr. 34, 593-598.

28. Sohn, H. Y., H. Y. Ryu, Y. S. Kwon, E. J. Kum, C. S. Kwon, G. S. K won, K. W. Kim, and K. H. Son. 2005. Screening of thrombin inhibitor from medicinal and wild plants (I). Korean J. Pharmacogn. 36, 263-272.

29. Sohn, H. Y., Y. S. Kwon, Y. S. Kim, H. Y. Kwon, G. S. Kwon, G. J. Kim, C. S. Kwon, and K. H. Son. 2004. Screening of thrombin inhibitors from medicinal and wild plants. Korean J. Pharmacogn. 35, 52-61.

30. Yoon, J. A., K. W. Yu, W. J. Jun, H. Y. Cho, Y. S. Son, and H. C. Yang. 2000. Screening of anticoagulant activity in the extracts of edible seaweeds and optimization of extraction condition. J. Korean Soc. Food Sci. Nutr. 29, 1098-1106.

\section{초록 : 35종 해조류 추출물의 in-vitro 항혈전 활성 평가}

\section{안선미 $\cdot$ 홍용기 ${ }^{1} \cdot$ 권기석 ${ }^{2} \cdot$ 손호용*}

(안동대학교 식품영양학과, ${ }^{1}$ 부경대학교 생물공학과, ${ }^{2}$ 안동대학교 생명자원과학부)

혈전성 질환을 예방, 개선할 수 있는 안전한 항혈전제를 개발하기 위해, 일반적으로 항혈전 효과가 있다고 알 려진 식용 해조류 35 종(갈조류 17종, 홍조류 11종 및 녹조류 7종)을 대상으로 메탄올 추출물을 조제하고, 이들의 thrombin time (TT), prothrombin time (PT), activated partial thromboplastin time (aPTT)을 평가하였다. 트롬빈 저해(TT)의 경우 35 종 중에서 감태, 곰피, 대황, 넓패, 패, 알송이모자반 및 야마다모자반에서 강력한 활성을, 프로 트롬빈 저해(PT)의 경우 트롬빈 저해활성이 나타난 7종 중 야마다모자반을 제외한 6종에서 강력한 활성을 확인하 였으며, 혈 액응고인자 저해(aPTT)에서는 감태, 곰피, 대황, 넓패, 패, 알송이모자반 및 톳에서 강력한 활성이 나타 닜다. 선별된 8종의 시료를 대상으로 다양한 농도에서 항혈전 활성을 평가한 결과 알송이모자반에서 가장 강력한 활성을 확인하였으며, 곰피, 대황 및 넓패가 효과적이었다. 항혈전 활성과 해조류 추출물의 총 flavonoid, 총 polyphenol, 총당 및 환원당 함량과의 상관 관계를 검토한 결과, 활성물질은 flavonoid성 물질로 추측되었으며, 선별 된 8종은 총 flavonoid 함량 및 총 polyphenol 함량이 매우 높은 특징을 나타내었다. 본 연구 결과는 경제적이면 서 대량공급이 가능한 식용 해조류로부터 신규의 안전한 항혈전제 개발이 가능함을 제시하며, 야마다모자반과 톳은 트롬빈 또는 혈장내 응고 인자에 대한 특이 저해제로 개발 가능함을 제시하고 있다. 